\title{
PENGARUH PENGATURAN CAHAYA STEP UP - STEP DOWN DAN PENAMBAHAN KALSIUM PADA RANSUM AYAM PETELUR TERHADAP PENAMPU.AN PRODUKSI, KUALTTAS TELUR DAN KANDUNGAN KALSIUM PLASMA DARAH
}

\author{
Riswantiyah ${ }^{1}$, Tri-Yuwanta ${ }^{2}$, Zuprizal ${ }^{2}$
}

\section{INTISARI}

Penelitian ini bertujuan untuk mengetahui pengaruh pengaturan cahaya step up - step down dan penambahan kalsium pada ransum terhadap penampilan ayam petelur, kualitas telur, ritme peneluran dan kandungan kalsium plasma darah dan tulang. Sebanyak 96 ekor ayam petelur Strain LohmanBrown MF-402 umur 16 minggu ditempatkan pada 24 petak kandang. Ayam dikelompokkan dalam 4 perlakuan cahaya yaitu cahaya terus menerus $C_{1}=24 \mathrm{~T}$ (Terang) : $0 \mathrm{G}$ (Gelap), $\mathrm{C}_{2}$ $=12 \mathrm{~T}: 12 \mathrm{G}$, cahaya step up $\mathrm{C}_{3}=12 \mathrm{~T}: 6 \mathrm{G}: 0 \mathrm{~T}: 6 \mathrm{G}$, setiap minggu cahaya dinaikkan 1 jam sehingga menjadi $12 \mathrm{~T}: 3 \mathrm{G}: 6 \mathrm{~T}: 3 \mathrm{G}$, cahaya step down $\mathrm{C}_{4}=12 \mathrm{~T}: 3 \mathrm{G}: 6 \mathrm{~T}: 3 \mathrm{G}$ setiap minggu cahaya diturunkan 1 jam sehingga menjadi $12 \mathrm{~T}: 6 \mathrm{G}: 0 \mathrm{~T}: 6 \mathrm{G}$. ayam dari setiap kelompok cahaya diberi pakan yang mengandung kalsium 3,6 \% $\left(\mathbf{K}_{1}\right)$ dan $5,1 \%\left(\mathbf{K}_{2}\right)$. Setiap kombinasi perlakuan diulang $3 \mathrm{kali}$, dan setiap ulangan terdiri dari 4 ekor ayam. Data yang diperoleh dianalisis dengan analisis variansi menggunakan Rancangan Acak Lengkap pola Faktorial $4 \times 2$. Hasil penelitian merunjukkan bahwa tidak ada interaksi antara pengaturan cahaya dan penambahan kalsium untuk semua variabel yang diukur kecuali pada indeks kerabang telur. Penggunaan cahaya berpengaruh tidak nyata terhadap konsumsi pakan, bobot ayam, berat telur, berat kuning telur, kandungan kalsium plasma darah dan tulang, tetapi pengaturan cahaya berpenganh nyata $(P<0,05)$ terhadap umur dewasa kelamin dan produksi telur. Penambahan kalsium berpengaruh tidak nyata terhadap umur dewasa kelamin, berat kuning telur dan kandungan kalsium tulang, tetapi penambahan kalsium berpenganuh nyata $(\mathrm{P}<0,05)$ terhadap konsumsi pakan, berat badan akhir, jumlah telur, berat telur, kandungan kalsium plasma darah dan ketebalan kerabang serta indeks kerabang telur. Berdasarkan hasil penelitian dapat disimpulkan bahwa pola cahaya step down meningkatkan jumlah produksi telur dan ketebalan kerabang telur tetapi kedewasaan kelamin relatif cepat. Peningkatan kalsium dari 3,6 menjadi 5,1\% meningkatkan kualitas kerabang yaitu tebal dan indeks kerabang telur tetapi menurunkan berat telur dan berat ayam. Kenaikan 1,5\% kalsium dalam ransum meningkatkan $77 \%$ kadar kalsium dalam darah dan 11,47\% pada kandungan kalsium tulang.

(Kata Kunci : Cahaya Step up - Step down, Penambahan Kalsium, Penampilan Produksi, Kualitas Telur, Kalsium Plasma Darah).

Buletin Peternakan 22 (4) : 152 - 162, 1998

\footnotetext{
${ }^{1}$ Fakultas Peternakan Universitas Jenderal Soedirman Purwokerto.

${ }^{2}$ Fakultas Peternakan Universitas Gadjah Mada Yogyakarta 55281.
} 


\section{THE EFEECT OF STEP UP - STEP DOWN LIGTING REGULATION AND CALCIUM ADDITION ON LAYING HEN FEEDING ON PRODUCTION PERFORMANCE, EGG QUALITY AND BLOOD PLASMA CALCIUM CONTENT}

\section{ABSTRACT}

The objective of this research was to determine the effect of step up - step down lighting regulation and calcium addition on layer performance, egg quality, oviposition rytme, blood calsium plasma and bone calcium content. Ninety six layers of Lohmann Brown MF - 402 strain age of sixteen week were kept on twenty four cages. Hens were classified for four treatments lighting pattern namely continous lighting $\mathrm{C}_{1}=24 \mathrm{~L}$ (lighting) : $0 \mathrm{D}$ (Dark); $\mathrm{C}_{2}=12 \mathrm{~L}: 12 \mathrm{D}$, step up lighting pattern $\mathrm{C}_{3}=12 \mathrm{~L}: 3 \mathrm{D}: 0 \mathrm{~L}: 6 \mathrm{D}$ light was increased one hour per week to reach $12 \mathrm{~L}: 3$ $\mathrm{D}: 6 \mathrm{~L}: 3 \mathrm{D}$ and step down lighting pattern $\mathrm{C}_{4}=12 \mathrm{~L}: 3 \mathrm{D}: 6 \mathrm{~L}: 3 \mathrm{D}$ light was decreased one hour per week to reach $12 \mathrm{~L}: 6 \mathrm{D}: 0 \mathrm{~L}: 6 \mathrm{D}$. Each birds of group of lighting were given $3.6 \%$ $\left(\mathrm{K}_{1}\right)$ and $5.1 \%\left(\mathrm{~K}_{2}\right)$ of dietary calcium. Each treatment combination consist of four hens, and they have three replications. Data collected were analyzed using analysis of variance of Completely Randomized Design (CRD) factorial pattern $4 \times 2$. The result of this research showed that no interaction between lighting regulation and calcium addition for measured of all variables, except on egg shell index. Feed consumption, body weight, egg weight, yolk weight, blood calcium plasma and bone calcium content were no affected by lighting regulation but was significantly effect $(P<0.05)$ on sexual maturity and egg production. The sexual maturity, yolk weight and calcium bone content was no affected by calcium addition but was significantly effect $(\mathrm{P}<0.05)$ on feed consumption, final body weight, egg number, egg weight, blood calsium content, shell thickness and egg shell index. The result of this research indicated that step up lighting pattern increased on egg production and shell thickness but relative accelerated of sexual maturity. Increasing of dietary calcium from 3,6 to 5,1 percent improved respectively on shell quality namely : shell thickness, shell index and 77 percent increased of blood calcium content and 11,47 percent on bone calcium content.

(Key Words : Step up - Step-down Lighting, Calsium Addition, Layer Hen Performance, Egg Quality, Blood Plasma Calcium.)

\section{Pendahuluan}

Ayam petelur apabila dipelihara dengan baik mampu memproduksi telur 250 sampai 300 butir per tahun. Produksi tersebut dapat dicapai apabila faktor bibit, pakan dan pengelolaan termasuk faktor lingkungan harus diperhatikan. Faktor lingkungan yang perlu diperhatikan antara lain : iklim, cahaya atau photoperiod, temperatur, kelembaban, aliran udara, tekanan udara serta faktor non teknis yaitu kebisingan, polusi dan lain - lain.

Indonesia yang terletak di daerah tropis yang sepanjang tahun dapat memperoleh cahaya yang melimpah. Cahaya merupakan proses primodial dalam pembentukan telur, dikemukakan oleh Tri - Yuwanta (1992) bahwa cahaya memegang peranan penting di dalam proses ovulasi dan pembentukan telur serta dapat digunakan untuk mengatur konsumsi pakan. Lebih jauh dijelaskan pencahayaan berselang pada ayam pembibit dapat mensinkronisasikan peneluran ( Tri Yuwanta dan Nys, 1990 ), sehingga telur akan tinggal lebih lama di dalam uterus saat pembentukan kerabang telur. Kerabang telur yang dihasilkan mempunyai kualitas baik hal ini diakibatkan mukosa uterus diberi kesempatan 
untuk mendeposisikan mineral ke dalam kerabang telur menjadi lebih lama dan lebih banyak.

Di Indonesia pengaturan cahaya untuk meningkatkan produksi telur dan sekaligus meningkatkan kualitas kerabang telur belum banyak dilakukan, pada umumnya penggunaan cahaya dilakukan 24 jam terus menerus selama waktu produksi, sehingga produksi telur, kualitas kerabang dan berat telur lebih rendah dibandingkan dengan negara - negara sub tropis.

Umur dewasa kelamin ayam dara yang dipelihara di bawah pencahayaan kontinyu, tergantung pada lama pencahayaan. Menurut Morris (1967) bahwa waktu pencahayaan 10, 12 atau 14 jam akan mempercepat waktu dewasa kelamin. Morris (1966) melaporkan bahwa cahaya kontinyu dari 6 jam dinaikkan menjadi 18 jam akan dewasa kelamin baik dalam pemeliharaan pullet. Program pencahayaan menurun (step down) dengan waktu pencahayaan kurang dari 10 jam memperlihatkan hasil yang lebih baik dari pada program pencahayaan meningkat (step up ) yang berakhir pada panjang hari 12 jam menjadi 14 jam dalam penundaan umur dewasa kelamin sebagai akibatnya telur yang dihasilkan mempunyai ukuran dan kualitas lierabang lebih baik, angka kematian rendah serta meningkatkan fase bertelur lebih lama (Proudfoot and Gowe, 1967); namun lebih baik bila dibandingkan program pencahayaan kontinyu 14T : 10G.

Agar diperoleh telur yang berkualitas maka pakan ayam harus tersusun dari bahan bahan yang serasi antara lain sumber mineral. Mineral mempunyai peranan sangat penting dalam tubuh. Unsur mineral di dalam tubuh hewan lebih kurang tiga sampai lima persen. Karena hewan sangat membutuhkan mineral, maka mineral harus disediakan dalam perbandingan yang tepat dalam jumlah yang cukup. Mineral sebagai bahan pakan diperlukan oleh tubuh seperti halnya asam animo, energi, vitamin, asam lemak esensial.
Kebutuhan mineral pada ransum unggas biasanya dikonsentrasilkan pada kebutuhan kalsium dan fosfor. Tri - Yuwanta (1992) mengemukakan bahwa kalsium yang merupakan faktor utama dari pakan yang berkaitan dengan kualitas kerabang telur. Ditegaskan oleh Sauveur dan Mongin (1974) bahwa penambahan kalsium pada sore hari pada ayam pembibit akan meningkatkan soliditas kerabang telur dan daya tetas telur. Pembentukan kerabang telur dilakukan pada malam hari yaitu beberapa saat setelah ayam menkomsumsi pakan terutama pada sore hari. Di dalam proses tersebut dibutuhkan mineral terutama kalsium yang cukup pada pakan yang di komsumsi, karena kalsium darah pada pagi hari rendah dan meningkat tajam pada malam hari saat pembentukan kerabang telur terjadi yaitu pada 10 - 12 jam setelah ovulasi, di samping ayam mampu melakukam adaptasi kebutuhan kalsium yang digunakan (Mongin and Sauvur, 1979) karena terjadi koinsidensi antara kebutuhan dengan waktu datangnya gelap sehingga absorpsi kalsium dari tulang meduler menurun pada malam hari (Farmer et al, 1986). Oleh karena itu Sauveur dan Mongin (1974) merekomendasikan penambahan grit kerang yang diberikan tiga jam sebelum gelap atau meningkatkan kandungan kalsium pada ransum yang diberikan pada sore hari.

Berlatar belakang dari uraian tersebut di atas maka telah dilakukan penelitian suatu kombinasi antara pengaturan cahaya step up step down dan penambahan kalsium dalam ransum untuk meningkatkan penampilan produksi serta kualitas telur dan kerabang tehur.

\section{Materi dan Metode}

Penelitian ini dilaksanakan di kandang percobaan Fakultas Peternakan Universitas Jenderal Soedirman Purwokerto. Digunakan 96 ekor ayam Lohmann Brown MF 402 umur 16 minggu. Kandang yang digunakan 24 ruangan yang di isi 24 unit kandang baterai 
masing-masing berisi 4 petak kandang dengan 4 ekor ayam/petak. Masing-masing ayam tersebut di bagi secara acak menjadi 4 perlakuan cahaya yaitu cahaya terus menerus $\mathrm{C}_{1}=24 \mathrm{~T}$ (terang) : $0 \mathrm{G}$ (gelap), $\mathrm{C}_{2}=12 \mathrm{~T}$ : $12 \mathrm{G}$, cahaya step up $\mathrm{C}_{3}=12 \mathrm{~T}: 6 \mathrm{G}: 0 \mathrm{~T}: 6$ $\mathrm{G}$ setiap minggu cahaya dinaikkan 1 jam setiap minggu sehingga menjadi $12 \mathrm{~T}: 3 \mathrm{G}: 6 \mathrm{~T}: 3$ $\mathrm{G}$ dan cahaya step down $\mathrm{C}_{4}=12 \mathrm{~T}: 6 \mathrm{G}: 6 \mathrm{~T}$ : $3 \mathrm{G}$ setiap minggu diturunkan 1 jam sehingga menjadi $12 \mathrm{~T}: 6 \mathrm{G}: 0 \mathrm{~T}: 6 \mathrm{G}$. Ayam dari setiap kelompok cahaya diberi pakan mengandung kalsium 3,6\%( $\left.\mathrm{K}_{1}\right)$ dan $5,1 \%$ $\left(\mathrm{K}_{2}\right)$. Setiap kombinasi perlakuan diulang 3 kali, dan setiap ulangan terdiri dari 4 ekor ayam.

Pengambilan data dilaksanakan selama 17 minggu dimulai pada saat ayam mulai bertelur. Selama uji penampilan ayam pada penelitian biologis dilaksanakan juga uji kualitas telur, kandungan kalsium plasma darah dan tulang.

Data yang diambil meliputi konsumsi pakan, berat badan ayam, poduksi telur harian (HDA), umur dewasa kelamin, berat telur, berat kuning telur, ketebalan kerabang dan indeks kerabang serta kandungan kalsium plasma darah dan tulang semua data dianalisis dengan analisis variansi menurut Rancangan Acak lengkap faktorial menggunakan microsoft SAS.

\section{Hasil dan Pembahasan}

\section{Penampilan ayam petelur}

Hasil penelitian tentang penampilan ayam petelur meliputi : konsumsi pakan, berat ayam, umur dewasa kelamin dan produksi telur disajikan pada Tabel 1.

\section{Konsumsi pakan}

Hasil analisis variansi menunjukkan bahwa tidak terdapat interaksi antara pengaturan cahaya dan penambahan kalsium terhadap konsumsi pakan demikian pula dengan pengaturan cahaya, tetapi penambahan kalsium berpengaruh nyata $(\mathrm{P}<0,05)$ terhadap konsumsi pakan.

Memurut Nys et al. (1976) ayam petelur yang dipelihara di bawah kondisi pencahayaan kontinyu aktivitas pola makannya terlihat aktif pada awal pencahayaan, sedangkan pada kondisi yang normal (siklus gelap dan terang yang normal) puncak konsumsi pakan terdapat pada 1 dan 4 jam sebelum gelap, terutama sebelum dan selama mulainya proses pembentukan kerabang telur (Mongin and Sauveur, 1979). Terlihat bahwa penambahan kalsium pada ransum dengan aras yang semakin meningkat akan menurunkan konsumsi pakan dan konsumsi energi. $\mathrm{Hal}$ ini mendukung pendapat Roland dan Bryant (1994) bahwa penambahan kalsium dari 2,5 menjadi $4,5 \%$ pada ayam pullet mengakibatkan penurunan konsumsi pakan dan energi. Patrick dan Schaible (1980) mengatakan bahwa pakan yang mengandung kalsium dalam jumlah yang berlebihan akan menghasilkan telur yang kecil, kosumsi pakan dan produksinya rendah. 
Tabel 1. Penampilan ayam petelur

\begin{tabular}{|c|c|c|c|c|c|}
\hline \multirow[t]{2}{*}{ Perlakuan } & \multicolumn{4}{|c|}{ Cahaya } & \multirow[t]{2}{*}{ Rerata* } \\
\hline & $\mathrm{C}_{1}$ & $\mathrm{C}_{2}$ & $\mathrm{C}_{3}$ & $\mathrm{C}_{4}$ & \\
\hline \multicolumn{6}{|c|}{ Konsumsi pakan (g) } \\
\hline $\mathrm{K}_{1}$ & 99,91 & 88,86 & 92,72 & 94,49 & $93,99^{A}$ \\
\hline $\mathbf{K}_{2}$ & 82,73 & 82,18 & 84,15 & 83,73 & $82,70^{B}$ \\
\hline Rerata $=$ & 91,32 & 84,57 & 88,49 & 88,11 & \\
\hline \multicolumn{6}{|c|}{ Berat ayam (kg) } \\
\hline$K_{1}$ & 1539,33 & 1604,45 & 1508,33 & 1640,33 & $1571,86^{A}$ \\
\hline $\mathrm{K}_{2}$ & 1328,78 & 1542,89 & 1397,56 & 1458,78 & $1432,00^{B}$ \\
\hline Rerata $^{0^{2}}$ & 1434,06 & 1573,67 & 1452,99 & 1549,55 & \\
\hline \multicolumn{6}{|c|}{ Umur dewasa kelamin (hari) } \\
\hline $\mathbf{K}_{1}$ & 142,5 & 154,7 & 148,3 & 148,0 & 148,3 \\
\hline $\mathbf{K}_{2}$ & 147,0 & 154,3 & 153,3 & 154,7 & 149,7 \\
\hline Rerata $^{\mathrm{na}}$ & $144,7^{b}$ & $154,4^{a}$ & $150,7^{\text {tb }}$ & $146,2^{b}$ & \\
\hline \multicolumn{6}{|c|}{ Produksi telur (\%) } \\
\hline $\mathbf{K}_{1}$ & 87,63 & 68,81 & 81,27 & 78,82 & $79,38^{A}$ \\
\hline $\mathbf{K}_{2}$ & 63,99 & 54,85 & 63,27 & 73,80 & $69,13^{B}$ \\
\hline Rerata ${ }^{*}$ & $75,81^{*}$ & $62,33^{b}$ & $72,57^{\mathrm{b}}$ & $76,31^{*}$ & \\
\hline
\end{tabular}

\section{Keterangan :}

m : tidak berbeda nyata

a,b : Superskrip dengan huruf yang berbeda pada baris yang sama menunjukkan perbedaan nyata $(\mathrm{P}<0,05)$

$N^{B}$ : Superskrip dengan huruf yang berbeda pada kolom yang sama menunjukkan perbedaan nyata $(\mathrm{P}<0,05)$

\section{Berat ayam}

Hasil analisis variansi menunjukkan bahwa interaksi antara pengaturan cahaya dan penambahan kalsium berpengaruh tidak nyata, demikian pula pengaturan cahaya kecuali penambahan kalsium berpengaruh nyata $(\mathrm{P}<0,05)$ terhadap berat ayam.

Berat ayam merupakan gambaran dari pertumbuhan, sedangkan pertumbuhan pada prinsipnya merupakan akumulasi mutrien yang teretensi dalam tubuh (Frandson, 1993) selaras dengan hal di atas nutrien yang terentensi pada masing-masing pengaturan cahaya tidak berbeda sehingga menghasilkan berat ayam yang tidak berbeda. Shafey et al. (1990) menyatakan bahwa di antara 3 strain broiler yang diteliti ternyata masing-masing mempunyai toleransi yang berbeda terhadap kandungan kalsium yang tinggi dalam pakan, strain yang sangat toleran terhadap konsentrasi kalsium yang tinggi ternyata lebih kuns dibandingkan dengan yang kurang toleran terhadap kandungan kalsium yang tinggi dalam pakannya. Lebih jauh dijelaskan ada hubungan positif antara konsentrasi kalsium dalam pakan dengan glukosa plasma, kalsium mempengaruhi sekresi insulin, selanjutnyanya insulin mempengaruhi proses lipogenesis pada hati, akibatnya unggas tipe gemuk/besar kurang toleran pada kandungan kalsium yang tinggi dalam pakannya bila dibandingkan dengan unggas tipe ringan/kecil.
Umur

bahws nyata cahays umur $c$

Morris diperlu disam? reprod pada a mempe Apabil terjadi jauh d dewase membe $3,6 \%$ kelami kalsiun kelami Lesson pakan jumlah menun akan m bertam mencer (Simon

Produl

bahwa nyata kalsium produk:

bahwa pullet $y$ $u p$ deng al. $(196$ up yan yang di kurva $p$ jumlah 


\section{Umur dewasa kelamin}

Hasil analisis variansi menunjukkan bahwa penambahan kalsium tidak berpengaruh nyata terhadap umur dewasa kelamin, namun cahaya berpengaruh nyata $(\mathrm{P}<0,05)$ terhadap umur dewasa kelamin.

North dan Bell (1990), kemudian Morris (1994) menyatakan bahwa cahaya diperlukan untuk aktivitas sehari-hari disamping itu juga diperlukan untuk proses reproduksi. Peningkatan pemberian cahaya pada ayam selama periode pertumbuhan dapat mempercepat tercapainya dewasa kelamin. Apabila pencahayaan dikurangi maka akan terjadi keterlambatan dewasa kelamin. Lebih jauh dijelaskan bahwa hubungan antara umur dewasa kelamin dan lamanya pencahayaan membentuk kurva linier. Penambahan kalsium $3,6 \%\left(\mathrm{~K}_{1}\right)$ mencapai rata-rata umur dewasa kelamin 148,3 hari sedang pada penambahan kalsium 5,1 \% $\left(\mathrm{K}_{2}\right)$ rata-rata umur dewasa kelamin baru tercapai pada umur 149,7 hari. Lesson dan Summer (1991) menyatakan bahwa pakan yang mengandung kadar kalsium dalam jumlah yang tinggi disamping akan memurunkan konsumsi pakan, berat badan juga akan menunda dewasa kelamin, seiring dengan bertambahnya umur kemampuan unggas dalam mencerna mineral juga mengalami pemurunan (Simons, 1987).

\section{Produksi telur}

Hasil analisis variansi menunjukkan bahwa pengaturan cahaya berpengaruh tidak nyata terhadap produksi tetapi penambahan kalsium berpengaruh nyata $(P<0,05)$ terhadap produksi telur.

Noles dan Smith (1964) melaporkan bahwa tidak ada perbedaan penampilan pada pullet yang mendapat mengaturan cahaya step up dengan cahaya kontinyu. Namun Siegel et al. (1963) menyatakan pengaturan cahaya step up yang dimulai dengan panjang hari 6 jam yang dinaikkan setiap minggu akan mengubah kurva produksi dan pada akhir sikhus produksi jumlah telur meningkat, peningkatan jumlah telur per ekor ayam mencapai 33 butir (King, 1959). Sykes (1983) menyatakan bahwa penurunan konsumsi pakan akan mengakibatkan gangguan pada proses pembentukan telur akibat konsumsi energi dan nutrien yang juga berkurang. Pemberian kalsium yang semakin meningkat memperlihatkan kecenderungan lambat dewasa kelamin (Lesson dan Summer, 1991), pencatatan produksi telur pada periode awal peneluran menunjukikan pada ayam yang mencapai dewasa kelamin lambat produksi telurnya rendah.

\section{Kualitas telur}

Hasil pengamatan kualitas telur meliputi : berat telur, berat kuning telur, ketebalan kerabang telur dan indeks kerabang tehur tertera pada Tabel 2.

\section{Berat telur}

Tidak terdapat interaksi antara pengaturan cahaya dan penambahan kalsium terhadap berat telur tetapi penambahan cahaya berpengaruh nyata $(P<0,05)$ terhadap berat telur.

Memurut Tucker dan Charles (1993) peningkatan berat tehur terdapat pada ayam yang memperoleh cahaya berselang kontinyu. Menurut Nys dan Mongin (1981); Sauveur dan Mongin (1983) terjadi peningkatan berat telur $2-3 \mathrm{~g}$, sedangkan cahaya kontinyu cenderung menurunkan berat telur, stimulasi cahaya berselang diskontinyu sama halnya dengan cahaya kontinyu menununkan berat tehur (Rowland, 1985).

Memurut NRC (1994) bilamana pakan mengandung kalsium tinggi berakibat menurunnya berat tehur, produksi dan konsumsi pakan sehingga menghambat pertumbuhan, hal yang sama dikemukakan oleh Roland et al. (1985) bila kandungan kalsium dalam pakan berlebihan akan menyebabkan menurunnya konsumsi pakan karena palatabilitas pakan yang rendah. 
Tabel 2. Hasil pengukuran kualitas telur

\begin{tabular}{|c|c|c|c|c|c|}
\hline \multirow{2}{*}{$\begin{array}{l}\text { Perlakuan } \\
\text { Kalsium }\end{array}$} & \multicolumn{4}{|c|}{ Cahaya } & \multirow[t]{2}{*}{ Rerata* } \\
\hline & $\mathrm{C}_{1}$ & $\mathrm{C}_{2}$ & $\mathrm{C}_{3}$ & $\mathrm{C}_{4}$ & \\
\hline \multicolumn{6}{|c|}{ Berat telur (g) } \\
\hline $\mathbf{K}_{1}$ & 50,14 & 49,89 & 49,69 & 51,11 & $50,21^{\wedge}$ \\
\hline $\mathbf{K}_{2}$ & 47,92 & 50,16 & 49,33 & 48,39 & $48,95^{\mathrm{B}}$ \\
\hline Rerata $^{\mathrm{as}}$ & 49,03 & 50,07 & 49,51 & 49,75 & \\
\hline \multicolumn{6}{|c|}{ Berat kuning telur (g) } \\
\hline $\mathbf{K}_{1}$ & 12,50 & 12,69 & 12,66 & 13,09 & 12,73 \\
\hline $\mathrm{K}_{2}$ & 12,39 & 12,54 & 12,21 & 13,03 & 12,54 \\
\hline Rerata ns & 12,44 & 12,62 & 12,43 & 13,06 & \\
\hline \multicolumn{6}{|c|}{ Ketebalan kerabang (mm) } \\
\hline $\mathrm{K}_{1}$ & 0,362 & 0,361 & 0,364 & 0,362 & $0,362^{B}$ \\
\hline $\mathbf{K}_{2}$ & 0,370 & 0,392 & 0,394 & 0,380 & $0,384^{A}$ \\
\hline Rerata* & $0.366^{\mathrm{b}}$ & $0,376^{a b}$ & $0,379^{\mathrm{a}}$ & $0,371^{\mathrm{ab}}$ & \\
\hline \multicolumn{6}{|c|}{ Indeks kerabang telur $\left(\mathrm{g} / \mathrm{dm}^{2}\right)$} \\
\hline $\mathrm{K}_{\mathbf{I}}$ & $8,13^{b x}$ & $7,78^{\mathrm{a}}$ & $8,03^{\text {ab }}$ & $8,05^{\star}$ & $8,00^{A}$ \\
\hline $\mathbf{K}_{2}$ & $7,83^{\text {sb }}$ & $8,42^{\text {cde }}$ & $8,55^{\mathrm{e}}$ & $8,51^{\text {de }}$ & $8,33^{\mathrm{B}}$ \\
\hline Rerata* & $7,98^{b}$ & $8,10^{25}$ & $8,29^{n}$ & $8,28^{2}$ & \\
\hline
\end{tabular}

Keterangan :

${ }^{n} \quad$ : berbeda tidak nyata

$a b$ : Superskrip dengan huruf yang berbeda pada baris yang sama menunjukkan perbedaan nyata $(\mathrm{P}<0,05)$

A, B : Superskrip dengan huruf yang berbeda pada kolom yang sama menunjukkan perbedaan nyala $(\mathrm{P}<0,05)$

\section{Berat kuning telur}

Hasil analisis variansi menunjukkan bahwa pengaturan cahays, penambahan kalsium dan interaksi berpengaruh tidak nyata terhadap berat kuning telur.

Peningkatan jumlah cahaya dilakukan pada ayam petelur selama periode pertumbuhan dapat mempercepat tercapainya dewasa kelamin dan sebaliknya pengurangan pemberian cahaya akibatnya sebaliknya. Hubungan antara pengaturan cahaya dan aktivitas reproduksi merupakan hubungan yang khusus meliputi : organ mata - susunan saraf - sistem hormonal selanjutnya terjadi pemrosesan perkembangan folikel, pemasakan, ovulasi, pembentukan telur dan proses peneluran (Boshouwers dan Nicaise, 1993). Ukuran kuning telur sangat dipengaruhi oleh perkembangan ovarium yang menghasilkan ovum. Selain itu berat badan ayam, umur saat mencapai dewasa kelamin, kualitas dan kuantitas pakan, penyakit dan keadaan lingkungan antara lain sistem perkandangan, temperatur maupun kelembaban berpengaruh terhadap berat kuning telur (Romanoff dan Romanoff, 1963). Pemberian pakan dengan penambahan kalsium yang tinggi dalam pakan kurang disukai oleh ayam karena mengurangi palatabilitasnya sehingga dapat dilihat berat kuning telur pada $\mathbf{K}_{2}$ cenderung memurun akibat menurunnya proses metabolisme pakan dan menurunnya berat badan ayam (Chen dan Shen, 1989).
Keteb:

kalsiun

ketebal

berpeny

ketebal

kan bal

kualitas

kekuate

pola c

(1977)

rata ker

cahaya

(2T: $4 \mathrm{C}$

ketebale

$0,349 \mathrm{~m}$

penamb:

$\mathrm{mm}$ sed $\%\left(\mathbf{K}_{2}\right)$

kalsium

$\mathrm{mm}$ ata

Romano sebanyal

kerabang

Indeiks :

bahwa ir

penamba

$(\mathrm{P}<0,05)$

demikian

penambal

meningka and Mon:

Cahaya

sinkronise tinggal le pembentu diberi wal mineral $k$ and Nys, kalsium indeks $\mathbf{k}$ 
Ketebalan kerabang telur

Pengaturan cahaya dan penambahan kalsium berpengaruh tidak nyata terhadap ketebalan kerabang tetapi penambahan kalsium berpengaruh nyata $(\mathrm{P}<0,05)$ terhadap ketebalan kerabang telur.

Sauveur dan Mongin (1983) mengatakan bahwa pola cahaya berselang memperbaiki kualitas kerabang telur dan meningkatkan kekuatan tekan kerabang telur dibandingkan pola cahaya kontinyu. Cooper dan Bamett (1977) bahwa cahaya klasik menghasilkan ratarata kerabang paling tipis dibandingkan dengan cahaya berselang (14T: 10G); (2T: $2 \mathrm{G}) \times 6$; (2T: $4 \mathrm{G}) \times 4$ dan $(2 \mathrm{~T}: 6 \mathrm{G}) \times 3$ berturut-turut ketebalannya adalah $0,331 \mathrm{~mm}, 0,351 \mathrm{~mm}$, $0,349 \mathrm{~mm}$ dan $0,345 \mathrm{~mm}$.

Rata-rata ketebalan kerabang telur pada penambahan kalsium 3,6\% $\left(\mathrm{K}_{1}\right)$ sebesar 0,362 mm sedangkan pada penambahan kalsium 5,1 $\%\left(\mathbf{K}_{2}\right)$ sebesar $0,384 \mathrm{~mm}$. Penambahan 1,5\% kalsium menambah ketebalan kerabang 0,022 $\mathrm{mm}$ atau 6,07\%. Menunut Romanoff dan Romanoff (1963) bahwa kalsium dalam pakan sebanyak $2 \%$ meningkatkan ketebalan kerabang $0,035 \mathrm{~mm}$ atau $\pm 10 \%$.

\section{Indeks Kerabang telur}

Hasil analisis variansi menunjukkan bahwa interaksi antara pengaturan cahaya dan penambahan kalsium berpengaruh nyata $(\mathrm{P}<0,05)$ terhadap indeks kerabang telur, demikian juga pengaturan cahaya dan penambahan kalsium.

Penggunaan cahaya berselang akan meningkatkan indeks kerabang telur (Sauveur and Mongin, 1983; Tucker and Charles, 1993). Cahaya berselang akan meningkatkan sinkronisasi peneluran sehingga telur akan tinggal lebih lama di dalam uterus pada saat pembentukan kerabang dan mukosa uterus diberi waktu lebih lama untuk mendeposisikan mineral ke dalam kerabang telur (Tri-Yuwanta and Nys, 1990). Di samping penambahan kalsium di dalam pakan akan meningkatkan indeks kerabang telur, dengan tersedianya kalsium yang cukup, cahaya berselang akan berinteraksi dengan absorbsi kalsium dalam pembentukan kerabang telur (Hurwitz et al, 1973) yang disitasi oleh Tri-Yuwanta, (1992), dalam intestinum kalsium diabsorbsi sekitar 40 $\%$ akan meningkat sampai dua kali pada saat terjadi pembentukan kerabang telur. Cahaya kontinyu 14T : $10 \mathrm{G}$ menghasilkan indeks kerabang yang lebih rendah dibandingkan penggunaan cahaya berselang kontinyu maupun diskontinyu.

Kandungan kalsium dalam plasma darah dan tulang

Rata-rata kandungan kalsium plasma darah dan tulang tertera pada Tabel 3.

\section{Kandungan kalsium plasma darah}

Pengaturan cahaya tidak berpengaruh terhadap kalsium plasma darah dan tidak terdapat interaksi antara pengaturan cahaya denan penambahan cahaya kaisium terhadap kandungan kalsium plasma darah dan kalsium tulang.

Kandungan kalsium plasma darah pada hewan berkisar $9-12 \mathrm{mg} / 100 \mathrm{ml}$ atau $9-12$ mg \% (Tillman et al., 1991), kadar tersebut sangat tergantung absorbsi dari saluran pencernaan dan mobilisasi dari tulang. Menunut Chen dan Shen (1989) konsentrasi kalsium plasma dipengruhi oleh aras kalsium pakan dari 1 sampai $4 \%$ baik pada ayam White Leghom maupun itik, namun lebih jauh dijelaskan bahwa konsentrasi kalsium plasma rata-rata lebih tinggi pada itik dibandingkan dengan ayam. Hal ini sebaliknya dilaporkan oleh Bar dan Hurwitz (1984) bahwa pengurangan kandungan kalsium pakan menyebabkan penurunan total kalsium plasma darah secara nyata. 
Tabel 3. Hasil pengukuran kalsium darah dan tulang

\begin{tabular}{|c|c|c|c|c|c|}
\hline \multirow[t]{2}{*}{ Perlakuan } & \multicolumn{4}{|c|}{ Cahaya } & \multirow[t]{2}{*}{ Rerata ${ }^{*}$} \\
\hline & $\mathrm{C}_{1}$ & $\mathrm{C}_{2}$ & $\mathrm{C}_{3}$ & $\mathrm{C}_{4}$ & \\
\hline \multicolumn{6}{|c|}{ Kalsium tulang (\%) } \\
\hline $\mathbf{K}_{1}$ & 4,33 & 4,60 & 7,67 & 11,30 & $6,97^{\mathrm{a}}$ \\
\hline $\mathrm{K}_{2}$ & 6,43 & 11,93 & 18,47 & 12,60 & $12,36^{b}$ \\
\hline Rerata $^{\text {th }}$ & 5,38 & 8,27 & 13,07 & 11,95 & \\
\hline \multicolumn{6}{|c|}{ Kandungan Kalsium plasma darah $(\mathrm{g} / 100 \mathrm{~mol})$} \\
\hline $\mathrm{K}_{1}$ & 22,86 & 24,49 & 24,38 & 19,89 & 22,91 \\
\hline $\mathbf{K}_{2}$ & 27,10 & 21,74 & 30,83 & 22,50 & 25,54 \\
\hline Rerata & 24.98 & 23,12 & 27,61 & 21,19 & \\
\hline
\end{tabular}

na: tidak berbeda nyata

":Superskrip yang berbeda pada kolom rerata kalsium plasma darah menunjukkan perbedaan nyata $(\mathrm{P}<0,05)$

\section{Kandungan kalsium tulang}

Hasil analisis variansi menunjukkan bahwa interaksi antara pengaturan cahaya dan penambahan kalsium, pengaturan cahaya dan penambahan kalsium berpenganuh tidak nyata terhadap kandungan kalsium tulang.

Pengaturan cahaya tidak berpengaruh terhadap konsumsi pakan sehingga jumlah kalsium yang dideposisikan pada tulang sama. Tillman et al. (1991) menyatakan bahwa komposisi tulang bervariasi tergantung pada umur hewan dan keadaan pakannya. Perbandingan kalsium dan fosfor berdasar-kan berat dalam tulang lebih kurang $2: 1$.

Shafey et al. (1990) melaporkan bahwa kandungan kalsium, imbangan kalsium dan fosfor dalam tulang tibia berbeda di antara strain demikian juga respon terhadap kalsium, fosfor dan vitamin $\mathrm{D}$ dalam pakan, sehingga menyebabkan ekskresi kalsium juga berbeda. Kelebihan vitamin D akan merangsang mekanisme aktif terhadap peningkatan absorpsi kalsium, kelebihan konsentrasi kalsium dalam pakan menambah absorpsi terutama difusi pasif namun kelebihan konsentrasi $\mathrm{Ca}$ atau $\mathrm{P}$ kemungkinan akan mengurangi ketersediaan unsur mineral yang lain akibatnya absorpsi kedua mineral itu akan berkurang.

\section{Kesimpulan}

Berdasarkan hasil penelitian tentang pengaturan cahaya step up - step down dan penambahan kalsium pada ayam petelur dapat disimpulkan :

1. Pengaturan cahaya step down memberikan hasil terbaik terhadap produksi telur dan ketebalan kerabang telur, meskipun kedewasaan kelamin relatif cepat.

2. Peningkatan kalsium dari 3,6 menjadi $5,1 \%$ meningkatkan kualitas kerabang telur yaitu tebal dan indeks kerabang telur, tetapi menurunkan berat telur dan berat ayam serta produksi telur.

3. Kenaikan 1,5 persen kalsium dalam ransum meningkatkan $77 \%$ kadar kalsium dalam darah dan hanya $11,7 \%$ pada kandungan kalsium tulang.

\section{Daftar Pustaka}

Bar, A. and Hurwitz. 1984. Egg Shell Quality Medullary Bone Ash, Intestinal Calcium and Phosporus Absorption and Calcium Binding Protein in Phosphorus Deficient Hens. Poult. Sci. 63 : 1975 - 1979. 
Boshouwers, F. M. G. and E. Nicaise. 1993. Artificial Light Sources and Their Influence on Physical Activity and Energy Expenditure of Laying Hens.

Chen, W. L. and T. F. Shen 1989. Comparative Studies on The Utilization of Calcium Between Laying Tsaiya Duck and Leghom Hen. Ajas Vol.2. $2: 67$-72.

Cooper, J. B. and B. D. Barnett. 1977. Photoperiod Study With Chicken Hens. Poult. Sci. 56 : 1832 - 1835.

Farmer M. S., R. Roland and A. J. Clark. 1986. Influence of Dietary Calcium on Bone Calcium Utilization. Poult. Sci. 65 : 337 - 344

Frandson, R. D. 1993. Anatomi dan Fisiologi Ternak Edisi 4. Gadjah Mada University Press.

King, D. F. 1959. Artificial Light for Growing and Laying Birds. Alabama Agricultural Experiment Station Progres Report Series. No. 72.

Lesson, S and J. D. Summer. 1991. Commersial Poultry Nutrition. Published by University Books. P.O. Box. 1326. Guelph. Ontario. Canada NIH 6 N8.

Mongin, P and B. Sauveur. 1974. The Specific Calsium Appetite of The Domestic Fowl. Food Intake Regulation in Poultry, p.p. 171 - 189. Edited by K.N. Boorman and B.M. Freeman. Brit. Poult. Sci.

Morris. T. R. 1966. Lighting Intensity for Growing and Laying Pullet. World's Poult. Sci. J. 22 : 156 - 157.

Morris. T. R. 1967. Lighting Programs for Growing and Laying Pullet. World's Poult. Sci. J. $23: 326$ - 335.

Morris, T. R. 1994. Lighting For Layer : What We Know and We Need to Know. World Poult. Sci. J. $50: 283$ - 287.

North, M. O. and J. A. Bell 1990. Commercial Chicken Production Mamual. an Avi Book Publishing. New York.
Nutrient Requirements of Poultry. 1994. The $9^{\text {thi }}$ Ed. Subcommitte on Pouitr Nutrition Board on Agriculture. NRC. National Academy Press. Washington, D.C.

Nys, Y, B. Sauveur, L. Lacassagne and P. Mongin. 1976. Food, Calsium and Water Intakes by Hens Light Continuously From Hactching. Brit. Poult. Sci. 17 : 351 - 358.

Nys, Y. and P. Mongin. 1981. The Effect of 6 - and 8 Hour Light - Dark Cycles on Egg Production and Pattern of Ovipositions. Brit. Poult. Sci. 22 : 391 - 397.

Patrick, H. and P. J. Schaible. 1980. Poultry Feeds and Nutrition. The $2^{\text {odd }}$. Ed. Avi Publishing Company. Inc. Westport, Connecticutt.

Proudfoot, F. G. and Gowe, R. S. 1967. The Effect of Photoperiodism and Reasing Period, Feed Restriction on The Perfomance of The Five Leghorn Strains. Poult. Sci. 46 : $1056-1072$.

Roland. Sr., D. A, M. Farmer and D. Marple. 1985. Calcium and Its Relation ship To Excess Feed Consumption, Body Weight, Egg Size, Fat Depositionm Shell Quality and Fatty Liver Hemorrhagie Syndrome. Poult. Sci. 64 : 2341 - 2350.

Roland. Sr., D. A. and M. Bryant. 1994. Influence of Calcium on Energy Consumption and Egg Weight of Commercial Leghorn. J. App. Poultry Res. 3 : 184-189.

Romanoff, A. L. and A. J. Romanoff. 1963. The Avian Egg. John Wiley and Sons Inc. New York.

Rowland, K. W. 1985. Intermittent Lighting for Laying Fowls : A Review. World Poult. Sci. J. $41: 5$ - 19.

Sauveur, B. and P. Mongin. 1974. Effects of Time Limited Calcium Meal Upon Food and Calcium Ingesti and Egg 
Quality. Brit. Poult. Sct. 15 : 305 313.

Sauveur, B. and P. Mongin. 1983. Performance of Layer Reared and or Kept Under Different 6 Hours Light Dark. Cycles. Brit. Poutt. Sct. 24 : 405 - 416 .

Shafey. T. M. 1993. Calcium and Growing Chicken : Effect of Ratio of Dietary Calcium to Available Phosphorus. World Poult. Sci. J. $49: 7$ - 15.

Shafey, T. M., M.W. McDonald and R. A. E. Pym. 1990. Effect of Dietary Calcium, Available Phosphorus and Vitamin D on Growth Rate, Food Utilization, Plasma and Bone Contituents and Calcium and Phosphorus Retention of Comercial Broiler Strains. Brit. Poult. Sci. 31 : $587-602$.

Siegel, H. S., N. L. Beane and C. E. Howes. 1963. Lighting Regimes as an Influence on Maturity and Productivity of Leghorn-Type Layers. Poult. Sct. 42 : 1064 - 1071.

Simmons, P. C. 1979. Calcium and Phosphorus Nutrition. Proceeding of The Second European Symposium on Poultry Nutrition. Troelstra. Beckbergen. Netheriands.

Simmons. P. C. M. 1987. Major Minerals in the Nutrition of Poultry. Poultry
Sci. Symposium No. 19. Edited by Fisher, C. and K.N. Boorman. Butterworths. London.

Steel, R. G. and J. H. Torrie. 1991. Prinsip dan Prosectur Statistika. Gramedia. Pustaka Utama. Jakarta.

Sykes, A. H. 1983. In Physiology and Biochemistry the Domestic Fowl. B. M. Frieman Ed. Vol. 4. Academic Press. London New York.

Tillman, A. L., H. Hartadi, S. Reksohadiprodjo, S. Prawirokusumo dan S. Lebdosoekojo. 1991. Illmu Makanan Ternak Dasar. Fak. Peternakan UGM. UGM Press. Yogyakarta.

Tri-Yuwanta and Y. Nys. 1990. Effect of Short Intermittent Lighting on Food Consumption and Performance Dwarf Broiler Breeder and Progeny. Brit. Poult. Sci. 31 : 603 - 613.

Tri-Yuwanta. 1992. Pengaturan Cahaya dan Pakan Alternatif pada Ayam Broiler Breeder : Pengaruhnya terhadap Pola Konsumsi Pakan. Ritme Peneluran. Persistensi dan Kualitas Telur. Sub Balai Penelitian Ternak Grati. Pasuruhan.

Tucker. S. A. and D. R. Charles. 1993. Light Intensity. Intermittent Lighting and Feeding Regimen During Rearing As Affecting Egg Quality. Brit. Poult. Sci. $71: 255$ - 266. 